\title{
Effectiveness of the Public Livelihood Programmes on the Demand for Education, Health and Water Services in Uganda: A Case of Sustainable Livelihood Pilot
}

\author{
James Wokadala ${ }^{1, *}$, Adrian Ssesanga ${ }^{2}$, Herbert Akampwera ${ }^{3}$ \\ ${ }^{1}$ Department of Planning and Applied Statistics, School of Statistics and Planning, Makerere University, Kampala, Uganda \\ ${ }^{2}$ Centre for Population and Applied Statistics, Makerere University, Kampala, Uganda \\ ${ }^{3}$ Department of Monitoring and Evaluation, Northern Ugandan Social Action Fund 3, Office of the Prime Minister, Kampala, Uganda
}

Received March 29, 2020; Revised May 26, 2020; Accepted June 4, 2020

Copyright $(2020$ by authors, all rights reserved. Authors agree that this article remains permanently open access under the terms of the Creative Commons Attribution License 4.0 International License

\begin{abstract}
The purpose of the study was to establish the extent to which the Sustainable Livelihood Pilot (SLP) project was effective in promoting welfare of the target poor households and particularly to ascertain the extent to which the intervention has improved demand for social services at household level. The assessment was premised on the livelihoods approach that serves as an instrument for investigating the poor peoples' livelihoods. The analysis was based on consumption expenditure model built; the beneficiary incidence analysis to measure the benefits derived from public spending to the households in social services of education, health and water. The analysis established there were significant (at 1\%) changes in household incomes in the SLP project hosting districts in Uganda. Further, there were significant increases in the mean spending in total, and by sector for education, health and water, and more so percent changes on education services are higher than water and health. It was noted that the SLP intervention significantly impacted on household budgets in that individuals that accessed the grant significantly improved their budgets on education (by 42.3\%), health (by 26.4\%) and water (by 48.2\%) respectively as compared to the base period. The project targeted mainly women to respond to global strategies of improving demand financing through women empowerment.
\end{abstract}

Keywords Livelihoods, Poor Households, Gender, Uganda

\section{Background}

Several countries and organizations have employed the
Sustainable Livelihoods Approaches and Frameworks to transform the well-being of their communities and particularly the households. The frameworks have been used for projects' design, implementation, analysis as well as effective monitoring (Ashley \& Carney, 1999; Joint \& Markets, 2017). The sustainable frameworks are premised on people centered, responsive, multi-level, partnerships, sustainable, dynamic and by applying a holistic perspective to ensure relevance to improving peoples' livelihoods. Although, the frameworks have good development initiatives and principles, question still remains, whether these approaches are pro-poor in the developing context like Uganda? The concept of sustainable livelihoods is becoming increasingly important in poverty alleviation rural agricultural development and resource management (Thennakoon, 2012). The term "sustainable livelihood” has been defined within the development context as people's capacity to maintain a living by surviving shocks and stress and enhancing their quality on a long-term basis (Baumann, 2000; Chambers, 1987; Hoon, Singh, \& Wanmali, 1997; Singh \& Wanmali, 1998). The empowerment of the poor is important in poverty alleviation. For it to be sustainable and efficient there should be an efficient combination of livelihood assets which generates more impact in meeting peoples' needs. The effectiveness of any livelihood strategy largely depends on how the rural poor access and use a range of different assets as they seek to sustain and improve their wellbeing. The array and the how different livelihood strategies employed depend on the level and kind of resources, implementation systems and structures (Department for International Development (DFID), 2001).

During the past 3 decades, government of Uganda (GoU) has undertaken various development initiatives, particularly creating more local administrative units to 
bring social services closer to the people. These local units are partly responsible for implementing social programmes and projects for central government, but there is little impact research of this policy measure, especially in rural parts of the country. It is argued that the GoU is using local governments as a strategy to smoothen the costs associated with economic reforms (Gelsdorf, Maxwell \& Mazurana, 2012; Green, 2008). There has been government commitments to basic services particularly education, health and water.

In terms of provision of education services, the GoU was among the first in Africa to establish universal primary education in 1996 and school fees for all primary school children was abolished. Free lower secondary education followed suit in 2007, and all these had positive effect on equitable access to basic education. This development initiative had positive impact on literacy and improved welfare of the households especially female headed (Gelsdorf, Maxwell \& Mazurana, 2012). In the health sector, the government strategic and investment plan aims to ensure 'equitable access to health services and outlines targets and strategies for improving health and nutritional outcomes in the households (MoH, 2010). Following the government commitment, the health sector spending as percent of total government budget increased from $7.3 \%$ in 2010/11 to $8.9 \%$ in 2016/17 (Lukwago, 2016). A major improvement in the health sector is the increase in demand for health services through exemption of fees payment by the poor and vulnerable groups; expanding community based health insurance schemes; and abolishing fees for health services at local community health centres (Yates, 2006). However, the extent of the effective demand of the health services by the female beneficiaries is not clearly articulated. In the water sector, while access to clean and reliable water remains to be challenge in Uganda, nationally, about half (49\%) of Ugandans have access to improved drinking water. This is attributed to sector-wide approach adopted in 2002 to enable the government and development partners to follow a single policy and expenditure programme. Since 2016, the SLP has greatly contributed to already existing development initiatives. The SLP objectives, design and implementation modalities are explained hereunder.

\section{The Rural Sustainable Livelihood Strategy and Implementation}

The sustainable livelihood pilot (SLP) is a government programme that sought to improve and sustain the household incomes of the vulnerable people by among others, increasing demand for social services such as health and education. This effort was possible through building strong village level community institutions of the poor and providing income support services to existing and new community interest groups (CIGs). The sustainable livelihoods project focused on universal coverage of the poor in the target villages while tapping on the already existing affinity poor community savings groups and mobilizing and supporting other poor households to form savings groups of their own. What is not clear is the extent of the impact of this livelihood intervention on the selected sub-populations. This study intends to use mixed-methods to examine the effectiveness of this public livelihood programme on the demand for education and health services in Uganda.

The SLP is part of the Third Northern Uganda Social Action Fund (NUSAF 3) project that was administered by the Office of the Prime Minister (OPM) in Uganda and is being implemented from 2016 to 2021 in 62 districts of Uganda. The programme seeks to establish a comprehensive safety net for vulnerable groups by creating temporary work opportunities through public works, providing grants to promote income generating activities and improving organization and monitoring mechanisms to promote transparency, accountability, coordination and program management. The sustainable livelihood sub-component (SLP) of the NUSAF 3 project was piloted in 9 districts of Kitgum, Gulu, Nebbi, Lira, Masindi, Kotido, Soroti, Butaleja and Kapchorwa.

The implementation of the SLP followed a community-driven development (CDD) approach summarized in three forms viz: - Form I was the social mobilization following the 5 core principles by saving groups, and formation as well as development of NUSAF SHGs in target villages. The SLP project was implemented with 570 self-help groups. Form II involved the formation and capacity building of Village Livelihood Improvement Committees (VLICs), preparation and approval of village revolving funds (VRF) application and fund disbursement to districts for VRF. A VRF worth ten thousand dollars (USD 10,000) was provided and managed at village level by the VLICs. Moreover, there was livelihood planning, business training and preparation of business plans by SHGs, establishing the VRF, and provision of short-term loans to SHGs through VLICs at an interest rate not exceeding 5\%. Form III involved the implementation of livelihood business plans by SHGs, and follow up support by community facilitators, formation of producer organizations, market linkages and value chain development and convergence with other development programs (education, health, water, and sanitation, etc.). The SLP also aimed at consolidating learning and prepared operational guidelines for sustainable livelihood interventions for future programming and/or closure of pilot project. In view of the above statement the present study attempts to enquire into the extent to which SLP is effective in promoting sustainable livelihoods of the target poor households in Northern Uganda and particularly to ascertain the extent to which the intervention has improved demand for social services at household level.

\section{Research Objectives}

The specific objectives of the study are to; 
a) Measure the change and incidences in household incomes before and after the programme;

b) Measure changes and incidences in per capita spending on water, education and health services;

c) Find out the correlations of household demand for education, health and water services.

\section{Conceptual Framework, Identification and Estimation Techniques}

\section{Conceptual Framework for the Sustainable Livelihoods Programme}

The SLP is premised on the Livelihoods Approach that serves as an instrument for investigating the poor peoples' livelihoods (Kollmair \& Gamper, 2002). The framework attempts to visualize the main drivers and correlates of influence to people's livelihoods (Figure 1). The framework represents the full diversity and simplification of situations to understand using quantitative, qualitative and participatory analysis at the household and community levels. The participatory approaches have been used to identify the correlates of sustainable rural livelihoods, providing an important means of addressing the problems and priorities of the people under study (Pasteur, 2001; Thennakoon, 2012; Wekwete, 1998).

The framework depicts poor people and communities as operating in a context of vulnerability, within which they have access to certain assets (human, social, physical, financial and natural). The owned and accessed assets gain their value and relevance through the prevailing social, institutional and organizational environments (Carney, 1998). The operating environments and contexts influence livelihood strategies and outcomes. Generally, the framework provides a checklist of issues and the linkages to each other. It also presents core influences, processes, interactions in association to livelihoods. The framework also works on the premise that a single asset can generate multiple benefits, for instance, if a household has secure access to land, they are likely to be well endowed with financial assets, as they can use the land for productive purposes and to secure loans as well (Chambers, 1987; Cline-Cole \& Environment in Africa, 1995; DFID, 2000; Nicol, 2000; Thennakoon, 2012).

The transformation mechanism of these frameworks are such that households engage in livelihood activities to acquire or smoothen consumption patterns including coping, adaptive or survival strategies as well as income earning. This study adopts the livelihood strategies as used and concentrated within the core activities; farming, laboring, selling of agricultural produces or farm products, trading, building works as well as livestock (Vorley, 2001). Worth to note that farming constitutes the main activity in the rural Uganda, whilst a minimal number of households depend on off-farm income sources. The aim of this paper was therefore to establish the effectiveness of the development livelihood strategies on transforming the lives of the rural households in Uganda. The next section provides the sampling and estimation techniques.

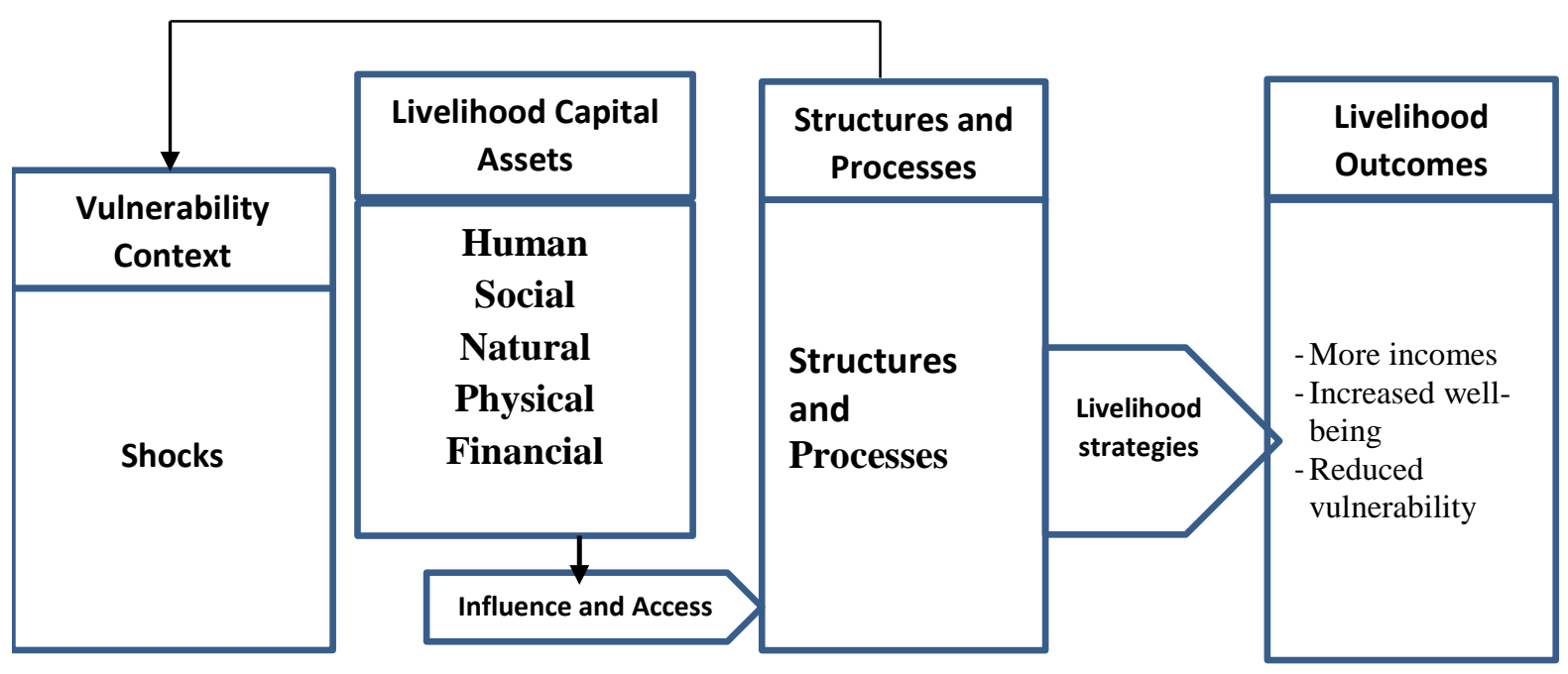

Source: Adopted from Kollmair and Juli (2002) ${ }^{1}$

Figure 1. Sustainable Livelihood Framework 


\section{Identification and Estimation Techniques}

The study employed cohort tracking approach, with no valid comparison group, to track the same beneficiaries interviewed at baseline and affected by the project. The beneficiary households and SHGs interviewed at the baseline were followed-up at the wave I survey. Attempts also were made to triangulate the analysis with other secondary sources from household surveys -to provide a descriptive understanding of the contribution of SLP to the poor using an evidence-based approach. The following steps were undertaken: (i) collected quantitative and qualitative data on SLP participation and current economic situation of the beneficiaries; (ii) engaged SLP project technical staff and elicited information on project implementation modalities; (iii) documented the key priorities that may need focus as well as the challenges; and (iv) proposed actionable recommendations.

The analysis was based on consumption expenditure model built following the works of Kirori, Mariara and Nganga (2011) and Ellis (2000) who state that rural households are assumed to maximize utility participating in diversified means of survival and improvement of their well-being. Drawing from the latter study, if say $W_{i}$ is the function of consumption expenditure. Let $X_{i}$ and $Y_{i}$ denote social and non-social capital goods demanded by the household $i$, so that $W_{i}=f\left(X_{i}, Y_{i}\right)$. Replacing $W_{i}$ which is unobservable with the quantifiable household consumption expenditure, $E_{i}$, then we have $E_{i}=$ $f\left(X_{i}, Y_{i}\right)$. The rural households use assets endowment to engage in productive activities either in enterprises within the households or in external labour markets. Thus the structural equation of the model is written as:

$$
E_{i}=a X_{i}+b Y_{i}+u
$$

Where $E_{i}$ is the total household expenditure on item $\mathrm{i}$

' $a$ ' vector of coefficients on endogeneous variables $(X)$

'b' vector of coefficients on exogeneous variables $(\mathrm{Y})$

The idea is that $E_{i}$ varies depending on the levels of social capital (X) such as net-works and non-social capital (Y) such as community social groups and $\mathrm{U}$ is the error term.

To measure the benefits derived from public spending on the households social services, say of education, health and water, the analysis followed the works of Demery (2000) who pioneered the basic steps in conducting benefit incidence analysis; and Wokadala and Barungi (2015) while analysing public spending under public-private schooling in Ugandan lower secondary education. The benefit incidence of the service of a specific group can be estimated as:

$$
X_{j}=\sum_{i=1}^{L} M_{i} \frac{s_{i}}{M_{i}}=\sum_{i=1}^{L} \frac{M_{j}}{M_{i}} S_{i} \quad \text { Where } \mathrm{j}=1,2,3, \ldots \ldots, 10
$$

Where $X_{j}$ is the benefit incidence accrued to income group $j$ from public spending on service $i(1,2,3, \ldots \ldots \ldots \ldots, L)$ denoted as $S_{i} ; M_{i j}$ represent the number of households spending on service $i$ from income group $j$ where each group is a decile; and $S_{i} / M_{i}$ is the unit cost of providing social service $i$. The social benefits to particular groups could as well be represented graphically to show incidence patterns by comparing Lorenz concentration curves which are used to assess the distribution of benefits of programmes. Thus, the curves are generated by plotting cumulative distribution of households by wealth decile or percentile. Thus, the concentration curves lying above the $45^{\circ}$ line of equality or the Lorenz curve reveal that the subsidy is more equally distributed or be judged as targeting the poor households while distribution curves below the diagonal indicate improper targeting or regressively targeting non-poor households. The concentration coefficient is estimated by the ratio of the bounded area below the perfect equality line say ' $\mathrm{A}$ ', which is numerically expressed as:

$$
A=\frac{1}{2}-\left[\frac{1}{n} \sum_{i=1}^{n-1} C_{i}+\left(\frac{1}{n}\right) C_{n}\right], C_{n}=1
$$

Where $C_{n}$ is a proportion of accepted benefit on the 45 degree line for each group of households, and ' $n$ ' $(=10)$ is the number of equal divisions. If the curve lies above the diagonal, it means that the poor decile gains more proportion of the total subsidy than the rich, while the distributions below the diagonal imply the poor or weaker targeting.

The data from selected themes and variables was analysed, that include but not limited to demographics such as gender and age, household incomes and expenditures; socio-economic indicators such as literacy levels of the household head, economic activities of the household members as well as livelihood support received by beneficiary households; and demand for selected social services such as education, health and water, respectively.

\section{Data and Descriptive Statistics}

The study used a mix of primary and secondary administrative data collected by Office of the Prime Minister (OPM) with support from Centre for Population and Applied Statistics (CPAS). Baseline data was collected in 2016 (from 1,230 household respondents) while wave I survey was conducted in 2018 (from 962 household respondents), respectively.

The sample was derived from a two-stage cluster stratified random sampling design with districts and sub-counties as clusters (PSUs), rural and urban village communities as strata. The survey covered 9 SLP districts of Kitgum (196 households), Gulu (304), Nebbi (277), Lira (49), Masindi (51), Kotido (44), Soroti (230), Butaleja (51) and Kapchorwa (33 households) at both the baseline and wave I survey, respectively. Within the district, there were urban cells and rural villages, with both male and females who benefited from the intervention. 
A total of 962 (out of 1,230) beneficiaries were followed at wave I survey posting an overall $78 \%$ rate. Overall, the baseline established that there were 2-8 groups per village, and there are about 30 members per group. Data was analysed in form of differences in means, beneficiary incidences as well as linear expenditure regression analysis and tests for robustness of the estimates using the appropriate tests.

The descriptive analysis reveals that the project mainly targeted females reported at $74 \%$ compared to only $26 \%$ male beneficiaries (Table 1). The ratio of baseline to wave I data points (respondents) was 56:44, and almost half $(48 \%)$ of the beneficiaries lie in the $>35-60$ years age bracket, and with $42 \%$ of them below the age of 35 years. Almost all (98\%) of the beneficiaries did not or had never received any other livelihood support before the SLP intervention implying the project well targeted the poor especially the women. However, it was also noted that $59 \%$ of the respondents were found involved in the activity that was social and/or economic in nature.

It was further observed that $65 \%$ of the beneficiaries were likely to be literate i.e. being able to read, write and understand the learning foundations of numeracy and literacy, respectively. The details on household expenditures on education, health and water are presented in Table 1.

The sections that follow indicate the evidence generated on the extent to which livelihood interventions impact on the poor's effective demand for social services. The analysis presents changes in household income by all and by district (before and after the SLP programme); the beneficiary incidence analysis depicting the winners and losers of the intervention; the household per capita spending on social services as well as the expenditure function analysis to establish correlates of household demand for education, health and water services in Uganda.

Table 1. Descriptive statistics of the variables

\begin{tabular}{|c|c|c|c|c|c|}
\hline Variable & Obs. & Mean & Std. Dev. & Min. & Max. \\
\hline Time $(=1)$ & 2,193 & 0.44 & 0.50 & 0.00 & 1.00 \\
\hline Sex $($ Female $=1)$ & 2,193 & 0.74 & 0.44 & 0.00 & 1.00 \\
\hline Age $(<=35$ years) & 2,193 & 0.42 & 0.49 & 0.00 & 1.00 \\
\hline Age (>35-60 years) & 2,193 & 0.48 & 0.50 & 0.00 & 1.00 \\
\hline Age $(>60+$ years $)$ & 2,193 & 0.10 & 0.30 & 0.00 & 1.00 \\
\hline Received other livelihood support (Yes=1) & 2,193 & 0.02 & 0.16 & 0.00 & 1.00 \\
\hline Involved in any other activity (Yes=1) & 2,193 & 0.59 & 0.49 & 0.00 & 1.00 \\
\hline Literate? (Yes=1) & 2,193 & 0.65 & 0.48 & 0.00 & 1.00 \\
\hline Log (HH total consumption expenditure) & 2,166 & 10.40 & 1.20 & -0.20 & 14.77 \\
\hline Log (HH expenditure on education) & 2,166 & 10.86 & 1.32 & -0.18 & 14.21 \\
\hline Log (HH expenditure on health) & 2,166 & 8.39 & 1.19 & -1.70 & 12.43 \\
\hline Log (HH expenditure on water) & 2,166 & 7.35 & 1.36 & 3.86 & 10.41 \\
\hline
\end{tabular}

Source: Baseline (2016) and Wave I Survey (2018) 


\section{Results and Discussion}

Table 2. Changes in household income by all and by district

\begin{tabular}{ccc}
\hline $\begin{array}{c}\text { District } \\
(\mathrm{n}=1,231)\end{array}$ & $\begin{array}{c}\text { Mean income (UGX) } \\
\text { at Baseline } \\
\text { (std error) }\end{array}$ & $\begin{array}{c}\text { \% change in } \\
\text { income at wave I } \\
\text { (p-value) }\end{array}$ \\
\hline All & $236,799(18,565)$ & $40.1 \% * * *$ \\
Butaleja & $320,072(72,483)$ & $18.4 \% * *$ \\
Gulu & $261,688(43,155)$ & $39.3 \% * *$ \\
Kapchorwa & $479,030(99,138)$ & $147 \% * * *$ \\
Kitgum & $241,727(20,070)$ & $58 \% * * *$ \\
Kotido & $269,659(55,861)$ & $44 \% * *$ \\
Lira & $231,800(101,687)$ & $36 \% * *$ \\
Masindi & $684,782(323,912)$ & $30 \% * *$ \\
Nebbi & $112,119(8,397)$ & $28 \% * *$ \\
Soroti & $201,717(27,851)$ & $2 \%$ \\
\hline
\end{tabular}

Source: Baseline (2016) and Wave I Survey (2018) data; *** $\mathrm{P}<0.01$, ** $\mathrm{P}<0.05$, * $\mathrm{P}<0.10$

The section presents results and discussion to respond to the objectives set in the study. The first objective was to measure changes and incidences in beneficiary household incomes before and after the programme intervention (Table 2). The analysis established there were significant (at 1\%) changes in household incomes in the 9 districts hosting the project. That is to say, there was an increase of $40.1 \%$ from the baseline of UGX 236,799 in the household incomes. Apart from Soroti district that reported insignificant increase of $2 \%$, the district of Kapchorwa and Kitgum recorded $147 \%$ and $58 \%$ increases in incomes from UGX 479,030 and UGX 241,727 and above the average. These can be well compared to Butaleja and Nebbi districts that recorded $18.4 \%$ and $28 \%$ increases in incomes from UGX 320,072 and UGX 112,119, respectively. The increases in incomes and the district variations therein are attributed to not only the grants provided to the majority of females, but also the type of income activity as well as the level of skilling to the beneficiaries. These findings are consistent with the findings by Carney (1998) who postulates that for an intervention to reduce poverty and lead to sustainable livelihood, it is critical that the poor are empowered to build on their opportunities. Carney's findings rhyme with the crust of results shared herein that point to ensuring that beneficiaries of the SLP grant also acquire a set of skills if their livelihoods are to be sustained. In their study on livelihoods, basic services and social protection in northern Uganda and Karamoja; Geldof, Maxwell, and Mazurana (2012) argued that a livelihood program moves from vulnerable populations towards viable groups with assets and the ability to take up opportunities to produce a surplus for the market. It is therefore not surprising that the SLP intervention had beneficiary households that had already formed into groups where they had savings that were hitherto not adequately exploited. It is however noteworthy that livelihood programs have the limitation of being less effective for beneficiaries that are unable to utilise the grant as per program design expectations.

\section{Per capita spending on education, health and water services}

The analysis on the changes in household per capita spending on education, health and water reveal significant changes in mean spending in total, and by sector. Overall, there was $38.2 \%$ significant (at $1 \%$ level) increase in total household spending from the baseline of UGX 51,297 (Table 3). In terms of specific sectors, there were $62.3 \%$, $27.0 \%$ and $15.9 \%$ significant increases in spending on education, water and health, respectively. These results largely reveal that effective household demand for social services actually increased after the programme intervention. These results agree with the findings of Krantz (2001) who found that program interventions by governments and development agencies seek to sustainably reduce poverty by empowering people with the propensity to demand and possess social assets such as nutrition, education, water and health that he also notes are termed as natural and human assets by different development agencies (Krantz, 2001). The increases in demand could be attributed to not only availability of the resources to spend but also the need for the household basic necessities.

Table 3. Changes in the household per capita spending on total and by sector

\begin{tabular}{ccccc}
\hline & $\begin{array}{c}\text { Total HH } \\
\text { spending }\end{array}$ & $\begin{array}{c}\text { Spending } \\
\text { on } \\
\text { education }\end{array}$ & $\begin{array}{c}\text { Spending } \\
\text { on health }\end{array}$ & $\begin{array}{c}\text { Spending } \\
\text { on water }\end{array}$ \\
\hline $\begin{array}{c}\text { Mean } \\
\text { spending } \\
\text { (UGX) at } \\
\text { Baseline }\end{array}$ & 51,297 & 75,138 & 8,321 & 2,840 \\
\hline $\begin{array}{c}\text { (Std error) } \\
\text { \% change } \\
\text { (p-value) }\end{array}$ & $38.2 \% * * *$ & $62.3 \% * * *$ & $15.9 \% *$ & $27.0 \% * *$ \\
\hline
\end{tabular}

Source: Baseline (2016) and Wave I Survey (2018); *** $\mathrm{P}<0.01$, ** $\mathrm{P}<0.05$, * $\mathrm{P}<0.10$

In terms of proportions of household spending on social services, it is observed that percent changes on education services are higher than water and health. Moreover, the proportions of household budgets on education are greater at baseline (59.5\%) and wave I (53.4\%) compared to spending on health and water, respectively (Figure 2). The education spending reveals the level of household burden on financing schooling as basic necessity. This could be attributed to increasing family needs for education at all levels compounded by the inevitably large family sizes in Uganda. Results from the 2014 Uganda Population and Housing Census (2014 UPHC) reveal that Uganda has $78 \%$ of its population below the age of 30 
years and is one of the youngest populations in the world (UBoS, 2016). The UPHC also indicates that $43 \%$ of the country's population is in school going ages of 6 to 22 years. Relatedly, the 2016 Uganda Demographic and Health Survey indicate that the country's fertility rate is currently 5.4 children per woman (Macro, 2016)

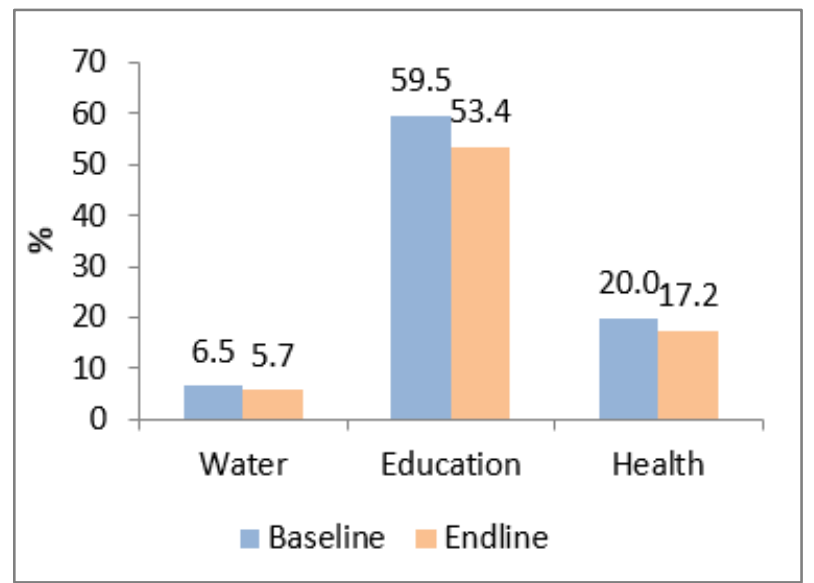

Source: Baseline (2016) and Wave I Survey (2018)

Figure 2. Proportions of household spending on social services to total

This section presents incidences in household total per capita spending and results are presented in Figure 3. The results indicate how the targeted grants are, using the cumulative distribution of population percentile against the cumulative percent of the grants provided. These Lorenz curves are statistical estimates and allow testing whether the curves lie at different ordinates (Wokadala \& Barungi, 2015). The results reveal that the baseline and wave I concentration curves lie slightly just above and below the line of perfect equality (PE) indicating how regressive $(\mathrm{CI}=0.038)$ the grants are - the subsidies are less equally distributed than the welfare before the intervention (Figure 3). This is attributed to the program design that targeted already existing saving groups without discriminating between wealth quintiles of group members. Whereas it may be argued that members of a given savings group tend to be homogenious, it was common to have savings groups with a mix of persons from different wealth quintiles and socio-demographic characteristics. Savings groups had a mix of the literate and semi-literate, persons in the low and middle wealth quintiles as well as a composition of at least $70 \%$ females and $30 \%$ males. The common attribute among members of a given savings group was the location of their places of residence as they all lived within the same neighbourhood.

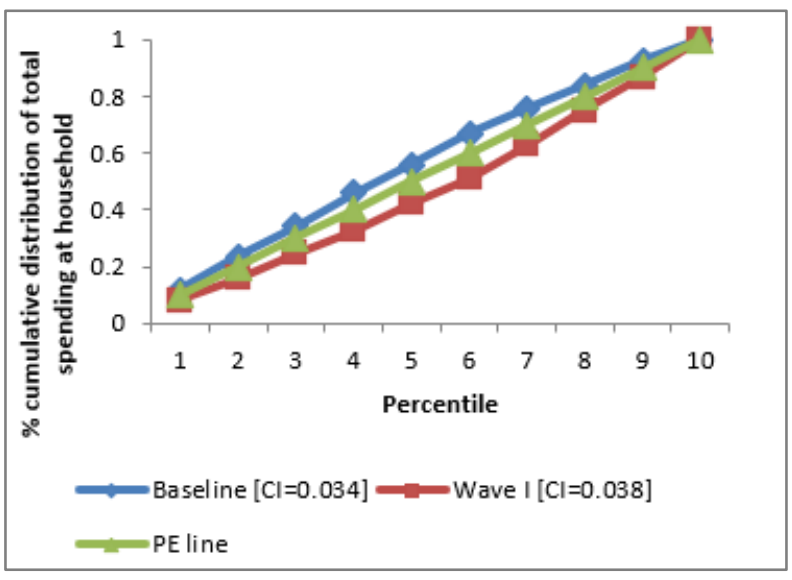

Source: Baseline (2016) and Wave I Survey (2018)

Figure 3. Benefit incidence curves of total spending at baseline and wave I

The regressivity is weaker along the percentiles as the concentration curves are closer to the line of perfect equality. Similar patterns are observed in spending to the sector specific services.

With regard to the sector specific spending, in the education (Figure 4) and health (Figure 5) sectors, the behaviour patterns of the wave I survey concentration curve is explained by the fact that members of savings groups were found to have had initiatives within the group to support each other towards raising funds to spend on education services. It is therefore reflected in the tendency of the baseline concentration curve to draw away from the line of perfect equality for the lower and middle percentiles.

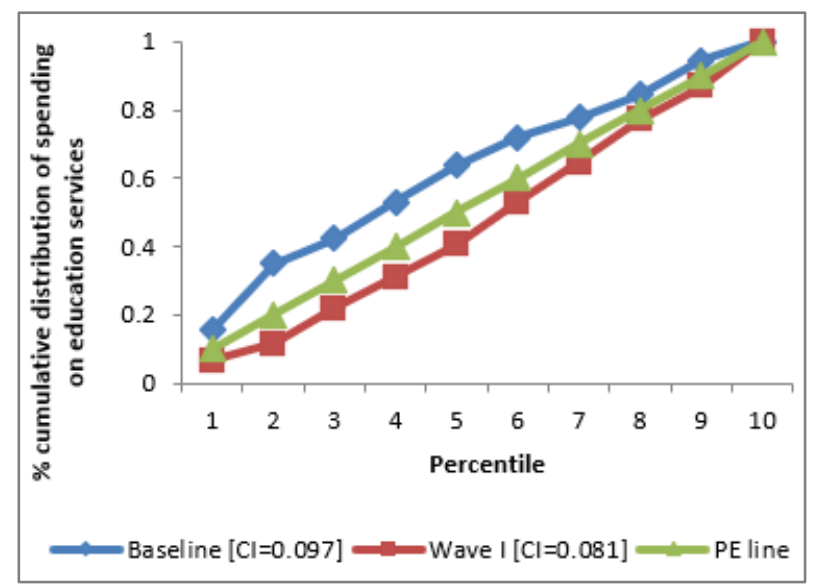

Source: Baseline (2016) and Wave I Survey (2018)

Figure 4. Benefit incidence curves of spending on education at baseline and wave I 
The wave I concentration curve shows more closeness to the line of perfect equality in comparison with the baseline. The closeness increases along the percentiles implying that the program was regressive. It is comprehensible that where there is non-discriminatory selection of members to join savings groups, households in the upper percentiles would only supplement the support accrued from the grant to already existing resources and the practise of spending on education services thus leading to the attainment of a line of perfect equality at the end of the intervention more to the disadvantage of those in the lower percentiles.

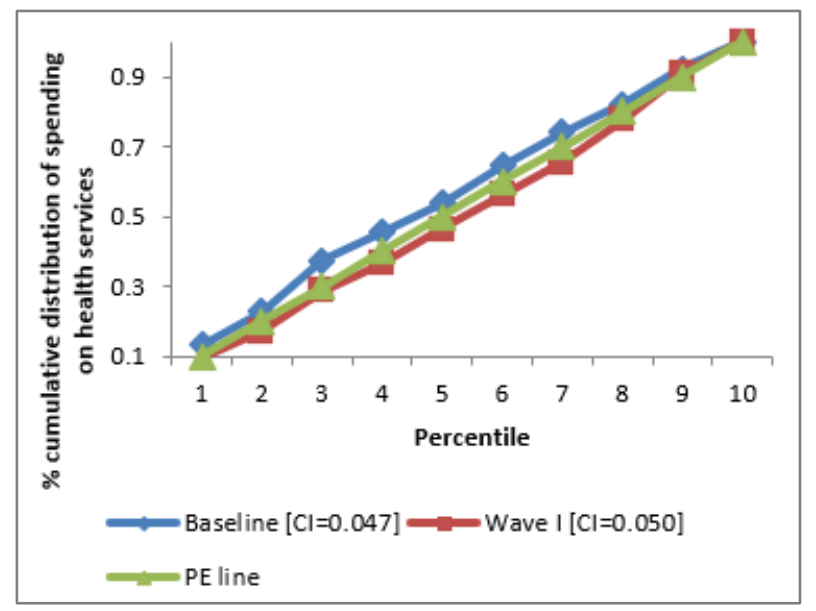

Source: Baseline (2016) and Wave I Survey (2018)

Figure 5. Benefit incidence curves of spending on health at baseline and wave I

In the water sector, the behaviour pattern of the wave I concentration curve is explained by the fact that water is more of a communal service than a household expense in the SLP beneficiary districts (Figure 6). At both baseline and wave I, the concentration curves are therefore close to the line of perfect equality across all percentiles. It is however imminent that person in the lower percentiles drew closer to the perfect equality line at wave I that the baseline concentration curves.

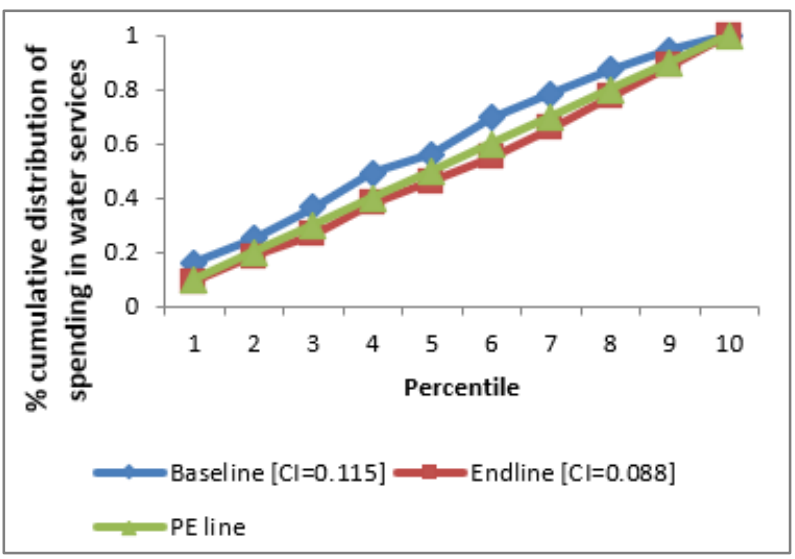

Source: Baseline (2016) and Wave I Survey (2018)

Figure 6. Benefit incidence curves of spending on water at baseline and wave I

As argued by Krantz (2001), a lack of access to social services such as water is recipe to the birth of poverty and should thus be more of a public good than a household expense. Interventions such as SLP are therefore a catalyst to bridge the gap of access without regard to the percentile that a household belongs to.

The results from the expenditure function are presented in Table 4. It is noted that the SLP intervention significantly impacted on household budgets. Estimates from direct effects and with interactions reveal that individuals that accessed the grant significantly improved their budgets on education (by $42.3 \%$ ), health (26.4\%) and water $(48.2 \%)$ respectively as compared to the baseline (Table 4). However, the significance of the intervention vanishes as we incorporate the interactions into the regression depicting some confounding factors remain relevant to influencing household budgets. This result is also a reflection of the findings by Maitra and Ray (2003) who found that whereas the marginal impact on household expenditures is influenced by the household's resource pool, expenditures on education, health and water remain prominent in both poor and non-poor households (Maitra \& Ray, 2003) 
Table 4. Correlates of household demand for education, health and water services

\begin{tabular}{|c|c|c|c|c|c|c|c|c|}
\hline & $\begin{array}{l}\text { Total HH } \\
\text { Spending }\end{array}$ & $\begin{array}{c}\text { Total HH } \\
\text { Spending+ }\end{array}$ & $\begin{array}{c}\begin{array}{c}\text { Spending } \\
\text { on educ }\end{array} \\
\end{array}$ & $\begin{array}{l}\text { Spending } \\
\text { on educ }+\end{array}$ & $\begin{array}{l}\text { Spending } \\
\text { on health }\end{array}$ & $\begin{array}{c}\text { Spending } \\
\text { on health+ }\end{array}$ & $\begin{array}{l}\text { Spending } \\
\text { on water }\end{array}$ & $\begin{array}{c}\text { Spending on } \\
\text { water+ }\end{array}$ \\
\hline DV-Spending & 1 & 2 & 3 & 4 & 5 & 6 & 7 & 8 \\
\hline Treat $(0 / 1)$ & $\begin{array}{c}0.325 * * * \\
{[0.055]}\end{array}$ & $\begin{array}{c}0.106 \\
{[0.117]}\end{array}$ & $\begin{array}{c}0.423^{* * *} \\
{[0.158]}\end{array}$ & $\begin{array}{c}-0.031 \\
{[0.269]}\end{array}$ & $\begin{array}{c}0.264 * * * \\
{[0.076]}\end{array}$ & $\begin{array}{c}0.171 \\
{[0.155]}\end{array}$ & $\begin{array}{l}0.482 * * \\
{[0.198]}\end{array}$ & $\begin{array}{c}0.497 \\
{[0.315]}\end{array}$ \\
\hline $\begin{array}{c}\text { Sex } \\
(\text { Female }=1)\end{array}$ & $\begin{array}{c}0.090 \\
{[0.059]}\end{array}$ & & $\begin{array}{c}0.235 \\
{[0.151]}\end{array}$ & & $\begin{array}{l}-0.076 \\
{[0.081]}\end{array}$ & & $\begin{array}{l}-0.318^{*} \\
{[0.171]}\end{array}$ & \\
\hline $\begin{array}{c}\text { Age } \\
(>35-60)\end{array}$ & $\begin{array}{c}0.052 \\
{[0.053]}\end{array}$ & $\begin{array}{l}-0.009 \\
{[0.053]}\end{array}$ & $\begin{array}{c}0.143 \\
{[0.142]}\end{array}$ & $\begin{array}{c}0.092 \\
{[0.143]}\end{array}$ & $\begin{array}{c}-0.282 * * * \\
{[0.072]} \\
\end{array}$ & $\begin{array}{c}-0.310^{* * * *} \\
{[0.072]}\end{array}$ & $\begin{array}{c}-0.494 * * * \\
{[0.162]} \\
\end{array}$ & $\begin{array}{c}-0.513 * * * \\
{[0.161]} \\
\end{array}$ \\
\hline $\begin{array}{c}\text { Age } \\
(>60+)\end{array}$ & $\begin{array}{c}-0.302 * * * \\
{[0.089]}\end{array}$ & $\begin{array}{c}-0.371 * * * \\
{[0.086]}\end{array}$ & $\begin{array}{c}0.146 \\
{[0.227]}\end{array}$ & $\begin{array}{c}0.100 \\
{[0.229]}\end{array}$ & $\begin{array}{c}-0.189 \\
{[0.120]}\end{array}$ & $\begin{array}{c}-0.245^{* *} \\
{[0.120]}\end{array}$ & $\begin{array}{c}-0.379 \\
{[0.283]}\end{array}$ & $\begin{array}{c}-0.390 \\
{[0.283]}\end{array}$ \\
\hline $\begin{array}{l}\text { Livelihood } \\
\text { (Yes=1) }\end{array}$ & $\begin{array}{c}0.091 \\
{[0.163]}\end{array}$ & $\begin{array}{c}0.125 \\
{[0.165]}\end{array}$ & $\begin{array}{c}-0.581 \\
{[0.454]}\end{array}$ & $\begin{array}{c}-0.673 \\
{[0.460]}\end{array}$ & $\begin{array}{c}-0.072 \\
{[0.222]}\end{array}$ & $\begin{array}{c}-0.022 \\
{[0.223]}\end{array}$ & $\begin{array}{c}0.308 \\
{[0.672]}\end{array}$ & $\begin{array}{c}0.438 \\
{[0.672]}\end{array}$ \\
\hline $\begin{array}{c}\text { Any activity } \\
\text { (Yes=1) }\end{array}$ & $\begin{array}{c}0.025 \\
{[0.055]}\end{array}$ & & $\begin{array}{l}-0.293^{*} \\
{[0.155]}\end{array}$ & & $\begin{array}{c}0.038 \\
{[0.075]}\end{array}$ & & $\begin{array}{c}0.171 \\
{[0.189]}\end{array}$ & \\
\hline $\begin{array}{c}\text { Literate } \\
(\text { Yes=1) }\end{array}$ & $\begin{array}{c}0.495 * * * \\
{[0.055]}\end{array}$ & & $\begin{array}{c}0.657^{* * * *} \\
{[0.141]}\end{array}$ & & $\begin{array}{c}0.260^{* * * *} \\
{[0.075]}\end{array}$ & & $\begin{array}{l}0.347^{* *} \\
{[0.176]}\end{array}$ & \\
\hline Treat*activity & & $\begin{array}{c}-0.256 * * * \\
{[0.080]}\end{array}$ & & $\begin{array}{c}-0.302 \\
{[0.186]} \\
\end{array}$ & & $\begin{array}{c}0.009 \\
{[0.103]}\end{array}$ & & $\begin{array}{c}0.067 \\
{[0.221]}\end{array}$ \\
\hline Treat*literacy & & $\begin{array}{c}0.389 * * * \\
{[0.086]}\end{array}$ & & $\begin{array}{c}0.662^{* * *} \\
{[0.191]}\end{array}$ & & $\begin{array}{l}0.200^{*} \\
{[0.111]}\end{array}$ & & $\begin{array}{c}0.326 \\
{[0.236]}\end{array}$ \\
\hline Treat*sex & & $\begin{array}{c}0.093 \\
{[0.090]}\end{array}$ & & $\begin{array}{l}0.432 * * \\
{[0.204]}\end{array}$ & & $\begin{array}{l}-0.057 \\
{[0.119]}\end{array}$ & & $\begin{array}{c}-0.480^{* *} \\
{[0.219]}\end{array}$ \\
\hline Constant & $\begin{array}{c}9.85^{* * *} \\
{[0.09]}\end{array}$ & $\begin{array}{c}10.28 * * * \\
{[0.044]}\end{array}$ & $\begin{array}{c}10.11^{* * *} \\
{[0.255]}\end{array}$ & $\begin{array}{c}10.45^{* * *} \\
{[0.136]}\end{array}$ & $\begin{array}{l}8.29 * * * \\
{[0.124]}\end{array}$ & $\begin{array}{l}8.44^{* * *} \\
{[0.061]}\end{array}$ & $\begin{array}{l}7.21 * * * \\
{[0.294]} \\
\end{array}$ & $\begin{array}{l}7.36 * * * \\
{[0.152]}\end{array}$ \\
\hline $\mathrm{N}$ & 2,166 & 2,166 & 2,166 & 2,166 & 2,166 & 2,166 & 2,166 & 2,166 \\
\hline $\mathrm{R}^{2}$ & 0.065 & 0.044 & 0.131 & 0.107 & 0.040 & 0.031 & 0.085 & 0.082 \\
\hline
\end{tabular}

Moreover, other correlates of household budgets on social services are the literacy level of the beneficiaries. The importance of literacy skilling is found and proven to yield economic returns (Bing, 2008) such as a literate individual was likely to incur total household spending of $49.5 \%$ more than the non-literates. The pattern of significant spending by the literates is observed across all the social services sectors.

Moreover, impacts on the beneficiary group that is literate raises the effect sizes and their significance, such that individual beneficiaries of the grant who are literate increased their total household spending by $38.9 \%$ compared to non-literate. Spending on education and health services by the literate was $66.2 \%$ and $20 \%$ more at wave I as compared to the baseline, respectively. Individual beneficiaries of either sex had their household spending on education significantly increased by $43.2 \%$ but the household spending on water reduced by $48.0 \%$. The increment in household spending on education by either sex is testament to the inclusiveness of the intervention with its benefits accruing to all persons that belong to a savings group indiscriminately. This argument is supported by Levine, Prosser, Evans and Reicher (2005) who postulate that members of a social group would ultimately receive uniform treatment because they share the identity of group belonging that fosters unity, togetherness and care for one another. The reduction on water expenditure is indicative of the fact that households have improved access to communal safe water sources. The most popular source in the SLP intervention areas is the borehole. With the trainings and sensitizations on safe water use and access that is a component of the SLP project design; it is appreciable that household spending on water has in turn reduced significantly. As earlier cited from the study by Krantz (2001), access to water ought to be a communal rather than a commercial good.

The effect of age, gender and literacy of the beneficiaries cannot be underscored given the project design and targeting. For instance, the project targeted mainly women to respond to global strategies of improving demand financing through women empowerment. The project also targeted the youthful women and men who usually encounter relatively heavy household economic burden of meeting social service needs such as education and health, whose impacts has been found significant. This can be expounded by the fact that the SLP project design targeted the active poor whose resolve for forming savings groups was to primarily acquire the tenacity to afford access to basic social services notably health, food and education. A great proportion of members to the savings groups were benefactors for the households they belonged to and shouldered the responsibility to ensure the welfare and sustenance of other members of the household. The effect of schooling particularly basic education is proven beyond this study. Elsewhere it is noted that basic education yields higher economic returns and is pivotal to the enhancement and staking of human capital (Bing, 2008; Deininger, 2003; Dustmann \& Glitz, 2011). 


\section{Conclusions}

In conclusion, the social protection programmes still matter to the poor in the development world. In particular, incomes were noted to increase thus improving the effective demand for those that benefited. The expenditures were also noted to raise for the project beneficiaries up and down the wealth quintiles. The results reveal that the wealth households seem to benefit more grant subsidy than the lower quintile individuals, though the difference is rather narrow as the Lorenz curve is closer to the line of perfect equality. The richer households seem to have more household social services needs and thus spend more financial resources. The concentration curves further reveal that the SLP grant is more regressive, and this was because of the programme design that was rolled out through already existing self-help groups. Although the results on beneficiary analysis provide an understanding of pro-poor targeting of social protection initiatives to attain equality and equity are not without limitations. The analysis assumes that all the subsidies are equal to unity which may not be the case. On the other hand, there is appreciation of the role of grants and design as well as implementation framework in effectively improving demand financing of social services. Literacy, gender composition and age groups are possible correlates of household welfare and ultimately effective demand for social services. However, these findings fall short of the measure of how much income would be increased to meet full cost of the social services to effectively guide and inform possible implications.

\section{REFERENCES}

[1] Ashley, C. and Carney, D. (1999). Sustainable Livelihoods: Lessons from early experience. London: DFID.

[2] Baumann, P. (2000). Sustainable livelihoods and political capital: Arguments and evidence from decentralisation and natural resource management in India: Citeseer.

[3] Bing, W. K. (2008). Education and inequality in the developing world. In Inequality in Education (pp. 86-127): Springer.

[4] Carney, D. (ed.) (1998) Sustainable Rural Livelihoods: What contribution can we make?. London: DFID.

[5] Chambers, R. (1987). Sustainable livelihoods, environment and development: putting poor rural people first. Brighton: Institute of Development Studies

[6] Cline-Cole, R., 1995. Livelihoods, sustainable development and indigenous forestry in dryland Nigeria. In: Binns, T. (Ed.), People and Environment in Africa. John Wiley and Sons, Chichester, pp. 171-185.

[7] Deininger, K. (2003). Does cost of schooling affect enrollment by the poor? Universal primary education in
Uganda. Economics of Education review, 22(3), 291-305.

[8] Demery, L. 2000. Benefit incidence: A practitioner's guide. Available at: http://www1.worldbank.org/publicsector/pe/practitioner.do c (accessed 25 July 2014)

[9] Department for International Development (2000). Sustainable Livelihood Guidance Sheets, http://www.livelihoods.org

[10] Department for International Development (2001). Poverty: Bridging the Gap. In: London, DFID.

[11] Dustmann, C., \& Glitz, A. (2011). Migration and education. In Handbook of the Economics of Education (Vol. 4, pp. 327-439): Elsevier.

[12] Gelsdorf, K., Maxwell, D., \& Mazurana, D. (2012). Livelihoods, basic services and social protection in Northern Uganda and Karamoja.

[13] Green, E. (2008). District creation and decentralisation in Uganda: Citeseer.

[14] Ellis, R. (2000). Rural Livelihoods and Diversity in Developing Countries, Oxford University Press, Oxford.

[15] Hoon, P., Singh, N., \& Wanmali, S. (1997). Sustainable livelihoods: Concepts, principles and approaches to indicator development: New York

[16] Joint, U., \& Markets, S. (2017). World Bank Energy Sector Management Assistance Programme (ESMAP).

[17] Kirori, Mariara and Nganga (2011). Rural Livelihoods in Kenya: The Role of Social Capital." Journal of International Business \& Finance. 3(1):1-27.

[18] Kollmair, M., \& Gamper, S. (2002). The Sustainable Livelihoods Approach: Training Input. Zurich, Switzerland: Development Study Group Zurich (DSGZ)

[19] Krantz, L. (2001). The Sustainable Livelihood Approach to Poverty Reduction. Division of Policy and Socio Economic Analysis Swedish International Development Agency (Sida)

[20] Levine, M., Prosser, A., Evans, D., Reicher, S. \& Bulletin, S. (2005). Identity and emergency intervention: How social group membership and inclusiveness of group boundaries shape helping behavior. 31(4), 443-453.

[21] Lukwago, D. (2016). Health Spending in Uganda Implications on the National Minimum Health Care Package.

[22] Macro, U. (2016). Uganda Demographic and Health Survey: Key Indicators Report. Retrieved from Kampala: http://dhsprogram.com/pubs/pdf/PR80/PR80.pdf

[23] Maitra, P., \& Ray, R. (2003). The effect of transfers on household expenditure patterns and poverty in South Africa. 71(1), 23-49.

[24] Ministry of Health (2010). Health Sector Strategic and Investment Plan II. Kampala: $\mathrm{MoH}$

[25] Nicol, A. (2000). Adopting a sustainable livelihoods approach to water projects: implications for policy and practice. London, UK: Overseas Development Institute. No. 33 
[26] Pasteur, K. (2001). Changing organisations for sustainable livelihoods. Brighton, UK: Institute for Development Studies.

[27] Singh, N., \& Wanmali, S. (1998). The sustainable livelihood approach: a concept paper. Paper presented at the Framework paper for the sustainable livelihoods workshop, University of Florida in Gainesville.

[28] Thennakoon, S. (2012). Factors influencing smallholder cropping systems in two agro-climatic zones of Sri Lanka. http://ir.lib.seu.ac.lk/handle/123456789/2850

[29] UBOS. (2016). The National Population and Housing Census 2014 - Main Report. Retrieved from Kampala, Uganda: Kampala

[30] Vorley, B. (2001). The chains of agriculture: sustainability and the restructuring of agri-food markets. In: London, IIED, WSSD Briefing Paper.

[31] Wekwete, N. (1998). Implications of economic structural adjustment programme on population and environment: the case of Shamva District. In: Institute of Development Studies (IDS), (UZ).

[32] Wokadala, J., \& M. Barungi (2015) Benefit incidence analysis of government spending on public-private partnership schooling under universal secondary education policy in uganda, Africa Education Review, 12:3, 381-397

[33] Yates, R. (2006). International Experiences in Removing User Fees for Health Services-Implications for Mozambique. LondonDFID Health Resource Centre. http://www.dfidhealthrc.org/publications/health_sector_fin ancing/06Yates01.pdf 